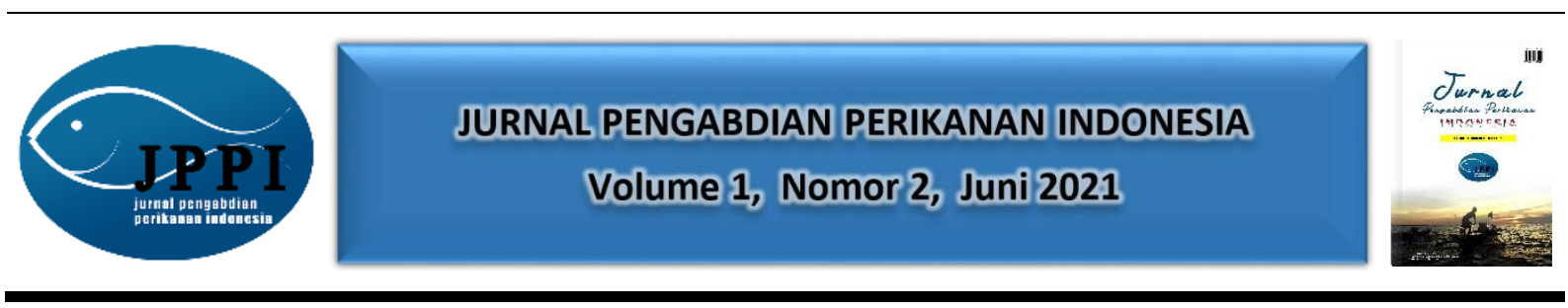

\title{
PENERAPAN TEKNOLOGI FIBERGLASS PADA PERAHU TRADISONAL NELAYAN DI DESA KARANG-KARANGAN KABUPATEN LUWU SULAWESI SELATAN Irman Halid, Budiawan Sulaeman, Nasruddin
}

\author{
${ }^{1}$ Program Studi Budidaya Perairan Universitas Andi Djemma Palopo, ${ }^{2}$ Program Studi Teknik \\ Informatika Universitas Andi Djemma Palopo, ${ }^{3}$ Program Studi Manajemen Universitas Andi Djemma \\ Palopo
}

Jalan Puang Haji Daud No. 4 Palopo, Sulawesi Selatan

Alamat korespondensi: irmanhalid@unanda.ac.id

(Tanggal Submission: 4 Juni 2021, Tanggal Accepted : 29 Februari 2021)

\section{Keyword: Abstrak:}

Perahu, Desa Karang-karangan merupakan daerah penghasil ikan Baronang Lingkis (Siganus tradisional, canaliculatus) yang merupakan produk perikanan favorit di Kabupaten Luwu. komposit, Beberapa permasalahan terhadap perahu tradisional yang digunakan oleh para fiberglass, nelayan, yaitu: (1) membuat perahu tradisional dibutuhkan papan/kayu, dengan Karang- jumlah bahan kayu yang semakin terbatas; (2) pembuatan perahu membutuhkan karangan. waktu yang cukup lama; (3) perbaikan atas kerusakan dan kebocoran sangat sulit diperbaiki dan perbaikan biasanya tidak bertahan lama. Tujuan dari kegiatan pengabdian masyarakat ini adalah penerapan teknologi fiberglass dalam bentuk pengenalan dan pelatihan material fiberglass terhadap perahu tradisional nelayan dengan fokus pada perubahan/pelapisan material fiberglass pada perahu tradisonal nelayan yang berbahan dasar kayu dalam upaya mendukung pengembangan perikanan laut. Metode yang digunakan adalah pemberian teori singkat dan praktik langsung tentang penerapan teknik pelapisan fiberglass. Hasil penerapan teknologi dalam bidang perikanan dalam wujud pengabdian kepada masyarakat mitra sebagai berikut: (1) pelatihan pengenalan material komposit kepada masyarakat nelayan, hal ini memberikan respon yang baik dalam mengikuti pelatihan; (2) penggunaan material komposit sebagai pelapis pada prerahu tradisional nelayan biaya perbaikannya lebih ringan dan mudah untuk dikerjakan; (3) respon dan antusias serta rasa ingin tahu masyarakat terhadap peralatan yang digunakan dalam produksi atau pembuatan perahu tradisonal memberikan energi positif; (4) minat peserta dalam pelatihan lanjutan mencapai $16 \%$ dan untuk memproduksi perahu berbahan dasar komposit mencapai $28 \%$.

Panduan Sitasi (APPA $7^{\text {th }}$ edition) :

Halid, I., Sulaeman, B., \& Nasruddin. (2021). Penerapan Teknologi Fiberglass Pada Perahu Tradisonal Nelayan Di Desa Karang-Karangan Kabupaten Luwu Sulawesi Selatan. Jurnal Pengabdian Perikanan Indonesia,

1 (2), 117-129. http://doi.org/ 10.29303/jppi.v1i2.121 


\section{PENDAHULUAN}

Secara geografis Desa Karang-karangan Kecamatan Bua Kabupaten Luwu merupakan daerah pesisir dan merupakan sentra perikanan ikan pelagis kecil Siganus canaliculatus atau dikenal dengan nama lokal malaja, terletak pada koordinat $3^{\circ} 6^{\prime} 27,19^{\prime \prime}-3^{\circ} 8^{\prime} 37,81^{\prime \prime}$ LS dan $120^{\circ} 14^{\prime} 4,35^{\prime \prime}-120^{\circ} 17^{\prime} 36,17^{\prime \prime}$ BT (Halid dan Mallawa, 2017). Pantai Karang-karangan merupakan salah satu tempat favorit masyarakat dalam menikmati kuliner jenis ikan malaja sekaligus sebagai tempat penelitian ekosistem lamun yang dimanfaatkan oleh masyarakat secara tidak langsung (Marhayana S. dkk., 2021). Dalam rangka meningkatkan pembangunan dan pengembangan Sumber Daya Manusia (SDM) masyarakat pesisir di Desa Karang-karangan, Kepala Desa Karang-karangan mengundang Tim Pakar Universitas Andi Djemma Palopo dalam kegiatan Musrenbang Desa untuk memperkaya muatan program bidang perikanan dan ekonomi kreatif pada tanggal 7 Februari 2020 (Gambar 1). Musrenbang desa dihadiri \pm 100 orang dan dihadiri pula oleh Camat Bua, Koordinator Tim Pendamping Kecamatan, Kepolisian Sektor Bua, Binmas, Tokoh masyarakat, Tokoh agama, Tokoh pemuda dan masyarakat. Dalam Musrenbang tersebut Tim Pakar Universitas Andi Djemma menyampaikan beberapa pokok-pokok pikiran yaitu bagaimana menjaga dan melestarikan lingkungan pesisir khususnya sumberdaya perikanan malaja, pengupayaan mata pencaharian alternatif serta penerapan teknologi pelapisan fiberglass untuk perahu tradisional nelayan. Selanjutnya dalam bidang ekonomi kreatif, bagaimana pengembangan pariwisata laut, bumdes bisa terorganisir dengan baik dan memberikan nilai tambah bagi masyarakat serta pengembangan koperasi nelayan (https://unanda.ac.id/2020/02/10/).

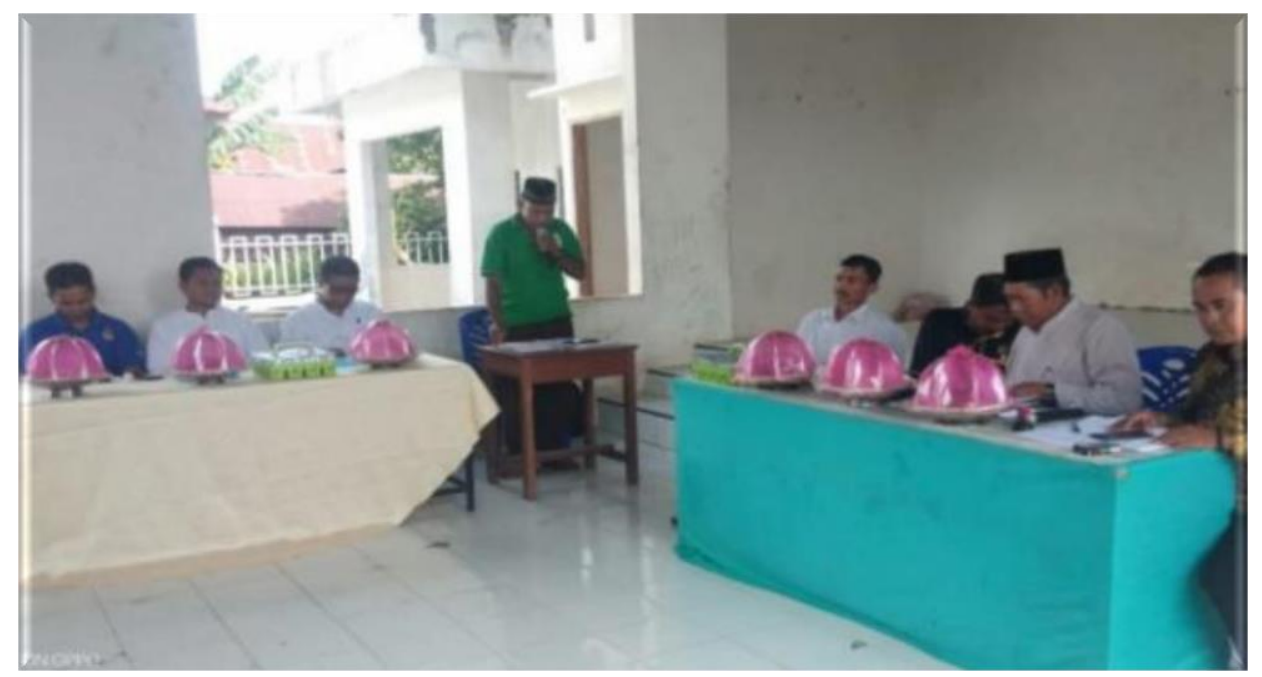

Gambar 1. Musrembang desa karang-karangan kec. bua kabupaten luwu

Nelayan penangkap ikan malaja merupakan nelayan skala kecil dengan mengandalkan perahu tradisonal. Perahu tradisional ini terbuat dari papan kayu yang dibentuk dengan ukuran sampan ratarata panjang 5 - 6 meter dan dapat mengangkut penumpang 3 - 5 orang (Gambar 2). 


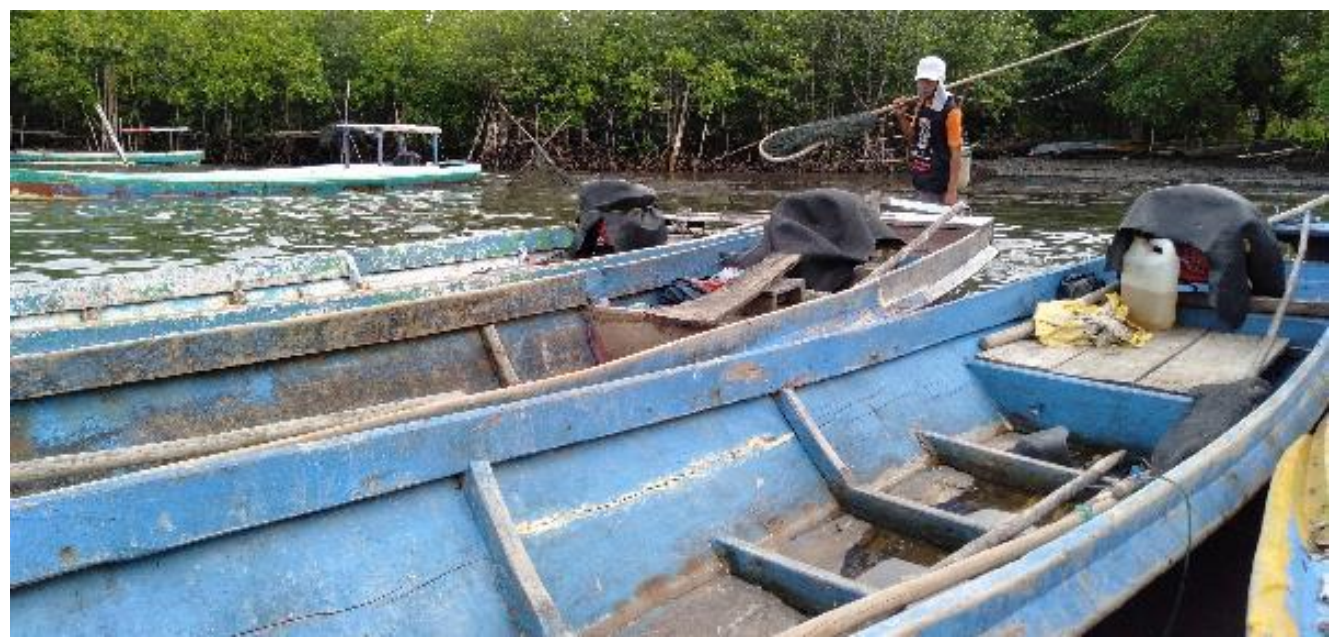

Gambar 2. Perahu tradisional nelayan penangkap ikan malaja

Berdasarkan hasil pengamatan dan koordinasi dengan masyarakat pesisir Desa Karangkarangan (mitra) ditemukan beberapa permasalahan terhadap perahu tradisional nelayan, yaitu:

\section{Perahu tradisional nelayan}

Pembuatan perahu sampan tradisional dibutuhkan papan kayu, dengan jumlah bahan kayu yang semakin terbatas dan kerusakan hutan dapat mengganggu kelangsungan dan keseimbangan makluk hidup dan dampak bencana alam (Nurul, 2018). Biaya pembelian kayu sangat mahal dan membutuhkan biaya atau sumber dana yang sangat besar. Bagi masayarakat pesisir di Desa karangkarangan sangat sulit untuk membelinya atau mengadakannya. Ditambah lagi dengan kerusakan yang terjadi pada dinding perahu tradisional, tidak dapat terbendung akibat gesekan air yang terjadi, berupa gesekan karang dan bertumpuknya parasit yang cepat berkembang, ini disebabkan karena kayu dengan kualitas kurang bagus banyak mengandung minyak sehingga parasit sangat menyukainya (Fardi, 2017).

\section{Pembuatan perahu nelayan}

Pembuatan perahu membutuhkan waktu yang cukup lama, untuk 1 unit perahu kayu dibutuhkan waktu pembuatan $\pm 6-7$ pekan. Berdasarkan hasil penelitian sebelumnya diketahui bahwa biaya produksi yang dikeluarkan kapal kayu lebih mahal jika dibandingkan dengan kapal fiberglass. Biaya penyusutan dan perawatan yang dikeluarkan kapal kayu juga lebih besar jika dibandingkan dengan kapal fiberglass (Khaerul, A., 2012).

\section{Perbaikan/maintenance perahu nelayan}

Perbaikan atas kerusakan dan kebocoran sangat sukar diperbaiki, jika menggunakan paku adakalanya bodi perahu retak dan pecah dan perbaikan biasanya tidak bertahan lama (Nurul, 2018). Jumlah bahan kayu yang semakin terbatas dan kerusakan hutan dapat mengganggu kelangsungan dan keseimbangan makluk hidup yang berdampak pada bencana alam, sehingga pengadaan material kayu harganya melambung tinggi. Diperlukan teknologi alternatif yang dapat meberikan solusi pada masalah tersebut dan salah satunya adalah penerapan teknologi fiberglass pada perahu tradisonal nelayan pesisir dan dapat meningkatkan ekonomi kreatif dibidang material komposit dengan memanfaatkan sumber daya manusia di Desa Karang-karangan. 
Berdasarkan pertimbangan tersebut, disepakati program pengabdian masyarakat dengan menerapkan teknologi fiberglass dalam bentuk pengenalan dan pelatihan material fiberglass terhadap perahu tradisonal nelayan. Fokus kegiatan pada perubahan/pelapisan material fiberglass pada perahu tradisonal nelayan yang berbahan dasar kayu serta untuk mengetahui antusias masyarakat Desa Karang-karangan dalam bidang ekonomi kreatif dalam upaya mendukung pengembangan perikanan laut di Desa Karang-karangan.

\section{METODE PELAKSANAAN}

\section{Pelaksanaan kegiatan}

Kegiatan dilaksanakan di aula pertemuan Desa Karang-karangan Kecamatan Bua Kabupaten Luwu Provinsi Sulawesi Selatan pada tanggal 15-16 Agustus 2020 dan target pelaksanaan kegiatan disusun berdasarkan diagram alir pelaksanaan kegiatan, terlihat pada Gambar 3.

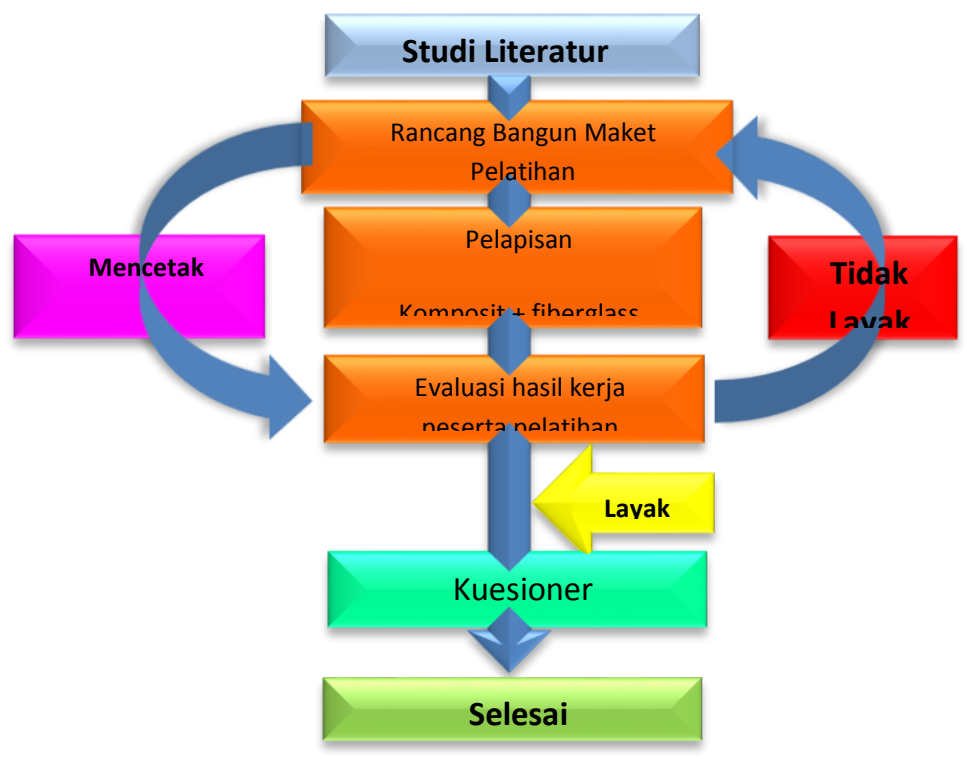

Gambar 3. Diagram alir pelaksanaan kegiatan

\section{Teknik pengenalan dan pelapisan material fiberglass}

Pelatihan menggunakan bahan dasar resin, katalis dan serat kaca (Sulaiman, 2015 dan Mazumdar, 2002) dan material (maket) yang terbuat dari kayu dan dilapisi oleh adonan komposit (resin dan katalis) yang diberi penguat fiberglass. Sebagai materi tambahan untuk menambah wawasan masyarakat nelayan di Desa Karang-karangan diperlihatkan cara mencetak perahu (mini) menggunakan adonan komposit. Bahan dasar komposit dicampur melalui proses pencampuran langsung antar material kemudian melapisi maket dengan metode hand lay up (olesan tangan).

\section{Metode pelaksanaan}

\section{a. Studi literatur}

Studi literatur dilakukan untuk mengetahui kebutuhan masyarakat Desa Karang-karangan yang menjadi mitra dalam pelaksanaan kegiatan pengabdian masyarakat dalam bentuk pelatihan dan metode pengumpulan data pustaka, membaca dan mencatat, serta mengelolah bahan dari lapangan(Danial dan Warsiah, 2007). 


\section{b. Pembuatan maket pelatihan}

Pembuatan maket menggunakan material kayu berbentuk kubus dilubangi disekelilingnya, bertujuan sebagai contoh kasus atau pendekatan yang terjadi dilapangan apabila perahu tradisonal nelayan mengalami kerusakan akibat keadaan alam dan lingkungan sekitarnya. Ukuran maket yang digunakan $20 \times 20 \times 30 \mathrm{~cm}$.

\section{c. Proses pelapisan komposit}

Sebelum diadakan proses pelapisan komposit pada maket, masyarakat dibekali pengetahuan dasar material proses pelkomposit. Setelah pelatihan selesai dilanjutkan dengan pelapisan komposit oleh peserta pelatihan dalam hal ini mayarakat nelayan di Desa Karang-karangan. Dalam pelapisan maket dilakukan dengan 3 tahap yaitu pelapisan dasar, pelapisan inti dan finishing.

\section{d. Pencetakan perahu mini}

Dilakukan dengan mengoleskan mirrorglass pada dinding cetakan (berulang), memoleskan adonan gelcoat (resin + katalis + talk) yang sudah dicampur dengan pigmen warna ke seluruh permukaan cetakan. Setelah kering maka serat fiberglass disusun secara rapi dan terdistribusi dengan sempurna dipermukaan cetakan hingga 5 - 6 lapisan mat di bagian bawah, empat lapisan di bagian tengah lambung dan tiga lapisan sampai pada pinggir atas badan perahu mini, kemudian dilanjutkan dengan pemolesan pada permukaan dengan adonan komposit. Setelah adonan mengering cetakan dibuka.

\section{e. Pemeriksaan}

Tahapan akhir dalam pelapisan maket adalah pemeriksaan seluruh permukaan maket yang telah dilapisi oleh material komposit + fiberglass dari kebocoran dengan cara memasukkan air kedalam maket untuk mengetahui kebocoran yang terjadi. Apabila masih ada air yang menetes maka dialakukan pelapisan ulang terhadap keborcoran yang terjadi.

\section{f. Kuesioner}

Tahapan ini merupakan pengumpulan informasi yang memungkinkan untuk dianalisis, mempelajari sikap-sikap, keyakinan, perilaku, dan karakteristik beberapa orang yang terlibat dalam pelatihan (Danial dan Warsiah, 2007).

Kuesioner berupa angket atau daftar pertanyaan yang harus diisi atau dijawab oleh responden (peserta pelatihan) untuk mengukur tingkat pemahaman, kepedulian dan skill responden dalam menerima materi pelatihan. Hal yang diharapkan melalui kuesioner adalah untuk mengetahui keadaan atau jangka panjang pelatihan yang telah dilalui oleh responden dalam menyukseskan kegiatan pelatihan dan dapat dikembangkan ketahapan selanjutnya.

\section{HASIL KEGIATAN}

\section{Pembuatan maket pelatihan}

Maket terbuat dari multipleks dengan ketebalan $5 \mathrm{~mm}$. Multipleks dipotong sesuai ukuran gambar kerja dinding depan $10 \times 20 \mathrm{~cm}$ dibuat 2 bagian, dinding samping $10 \times 10 \mathrm{~cm}$ dibuat 2 bagian dan alas $10 \times 20$ dibuat 1 bagian. Maket tersebut dilubangi dinding dan alasnya menggukan bor tangan $\varnothing 10 \mathrm{~mm}$. Semua bagian tersebut disatukan menggunakan paku $1 \mathrm{~cm}$, sehingga berbentuk seperti $\operatorname{kotak}$ (Gambar 4). 


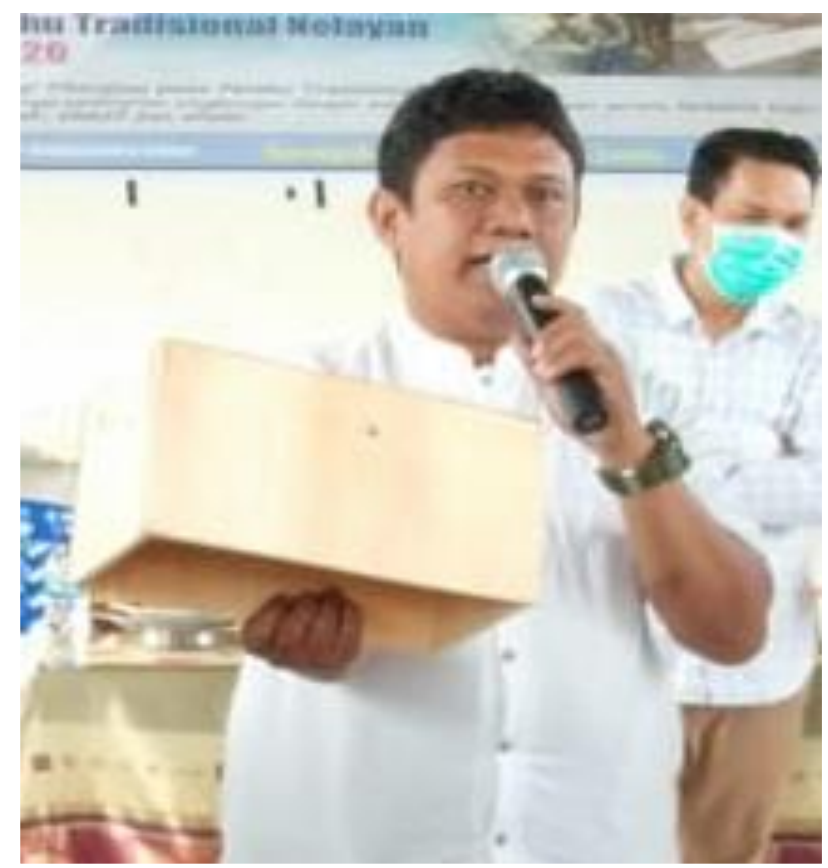

Gambar 4. Maket pelatihan

\section{Pengenalan material komposit}

Material komposit terdiri dari resin, katalis dan fiberglass (serat kaca). Adapun bahan tambahan yang digunakan adalah talk dan pigmen sebagai pewarna (Sulaeman, 2012 dan Akovali, 2001). Pengenalan material komposit meliputi proses pencampuran material dasar sehingga menjadi adonan yang siap untuk digunakan sebagai material pelapis pada material kayu, dimaksudkan untuk memperpanjang umur penggunaan material kayu yang terdapat pada perahu tradisional nelayan sehingga bernilai ekonomis dalam melapisi perahu tradisonal nelayan dengan fiberglass.

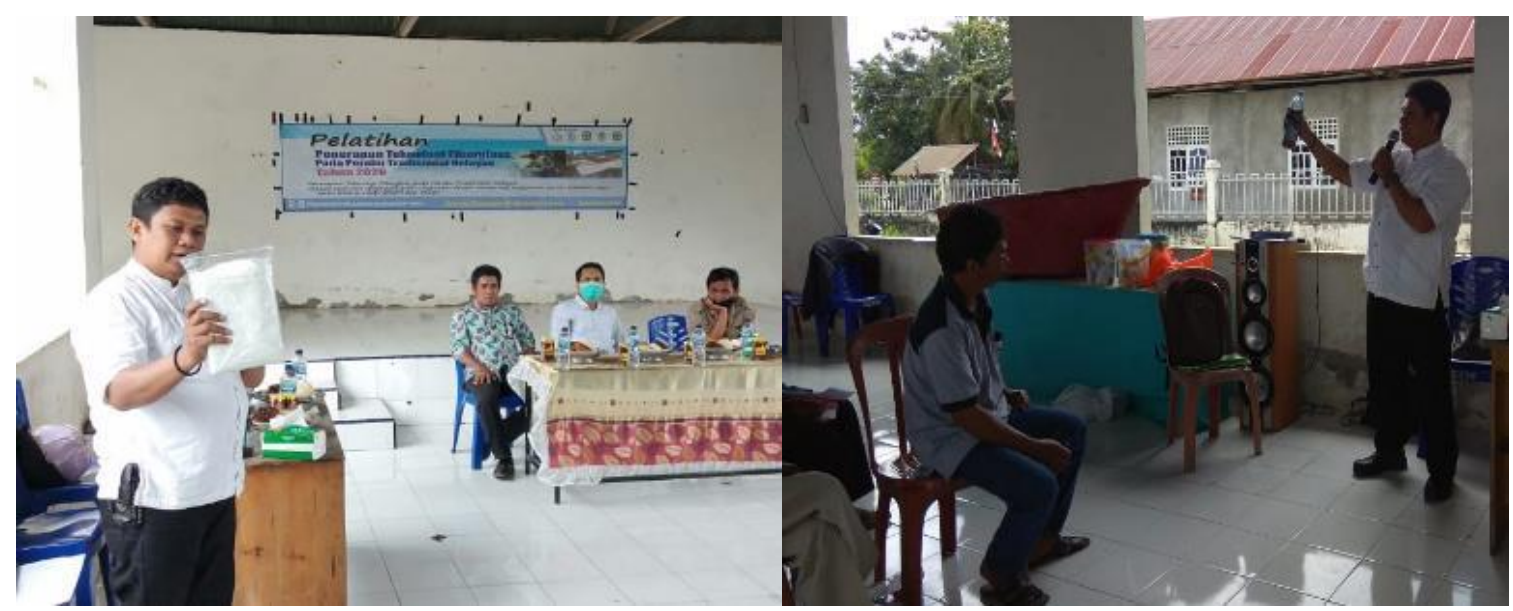

Gambar 5 . Pengenalan bahan dasar komposit (resin, katalis, talk dan serat kaca)

\section{Pelatihan penggunan material}

Peserta pelatihan dalam hal ini masyarakat terjun langsung dalam praktikum atau melakukan pelapisan pada maket dengan tujuan dapat melaksanaan langung atau kontak langsung dengan material komposit. Dalam pelatihan dilakukan beberapa tahap sebagai berikut: 


\section{a. Pelapisan dasar}

Melakukan pencampuran material komposit yang terdiri dari katalis, resin, talk dan pewarna dengan perbandingan $1: 10$ dan penggunaan talk mencapai 40\% kemuadian pewarna atau pigmen secukupnya. Pelapisan dasar bertujuan untuk melekatkan material komposit dengan kayu yang menjadi maket. Proses yang dilakukan dengan metode hand lay up, dioles menggunakan kuas pada semua permukaan maket sehingga tertutupi secara merata oleh material komposit.

\section{b. Pelapisan Inti}

Setelah pelapisan dasar mengering, diberikan lapisan serat gelas (fiberglass) pada permukaan maket sehingga maket tertutupi secara keseluruhan. Selanjutnya diolesi dengan komposit menggunakan kuas dengan cara menekan sedikit demi sedikit. Hal ini bertujuan untuk mengisi rogga yang terdapat pada permukaan fiberglass sehingga semua lapisan tertutupi dengan material komposit secara merata. Hal ini dilakukan secara berulang sebanyak 3 lapisan.

\section{c. Finishing}

Melakukan proses akhir setelah permukaan maket mengering. Proses ini untuk memperhatikan jangan sampai masih ada permukaan yang belum merata dan berongga, sehingga perlu dilakukan pengecekan ulang dan dilapis dengan material komposit sebanyak \pm 2 kali oles menggunakan kuas.

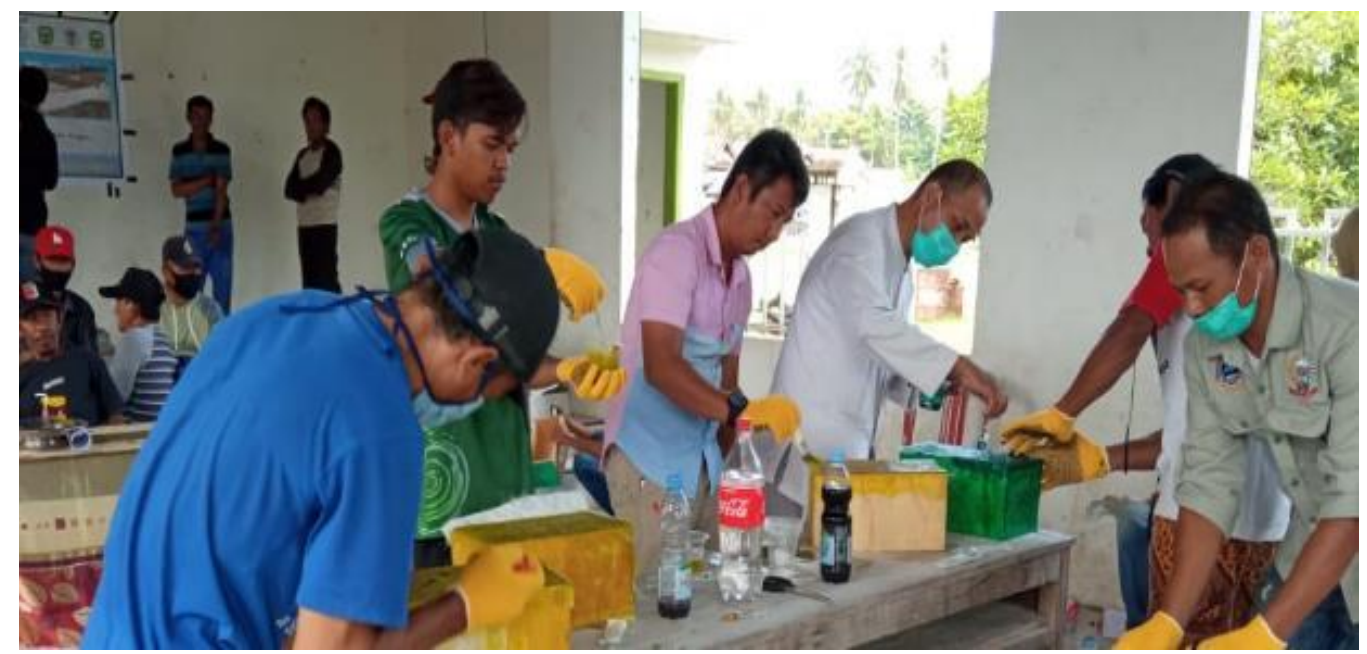

Gambar 6. Proses pelatihan masyarakat nelayan

\section{Pengujian hasil pelatihan}

Pengujian maket yang telah dilapisi komposit dan fiberglass dilakukan pada saat material komposit mengering. Maket dari hasil karya peserta dimasukkan ke dalam baskom kemudian diperhatikan apakah masih ada air yang menetes masuk kedalam maket. Apabila hal tersebut terjadi, maka ditandai sisi mana yang masuk air. Adapun langkah-langkah yang ditempuh untuk mengatasi hal tersebut adalah sebagai berikut:

a. Mengupas dengan menggunakan gerinda pada sisi yang terjadi peresapan air hingga kayu yang terdapat pada maket kelihatan;

b. Melakukan proses awal (melapisi sisi yang terindikasi terdapat celah atau rongga);

c. Setelah mengering, diberikan fiberglass pada lapisan tersebut secara berulang dengan cara menekan sedikit demi sedikit hingga 3 lapisan dan dilakukan finshing. 


\section{Pencetakan perahu berbahan fiberglass}

Tujuan proses ini untuk memperlihatkan kepada peserta proses pembuatan perahu berbahan dasar komposit yang diperkuat menggunakakan fiberglass. Pada pencetakan perahu material komposit dengan menggunakan resin, katalis, talk dan pewarna yang diperkuat dengan serat gelas (fiberglass). Tahapan pertama adalah melapisi permukaan cetakan/mall dengan bahan anti lengket (mirrorglaze). Selanjutnya dapat dilapisi dengan gelcoat yang telah dicampur dengan pigmen warna. Jadi perahu material komposit sudah diberikan warna sejak proses pencetakannya dan tidak perlu dilakukan proses pengecatan lagi. Setelah gelcoat kering dan mengeras sekitar 20-25 menit, maka fiberglass diletakkan dipermukaan cetakan dengan rapi dan rata. Jika terdapat bagian yang tidak sesuai dengan cetakan, fiberglass dapat dipotong dengan menggunakan gunting, setelah semua serat terlihat rapih dan rata. Dilanjutkan dengan hand lay up/pemolesan serat dengan menggunakan material komposit secara perlahan dan ditekan sedikit demi sedikit seperti pada Gambar 7 berikut.

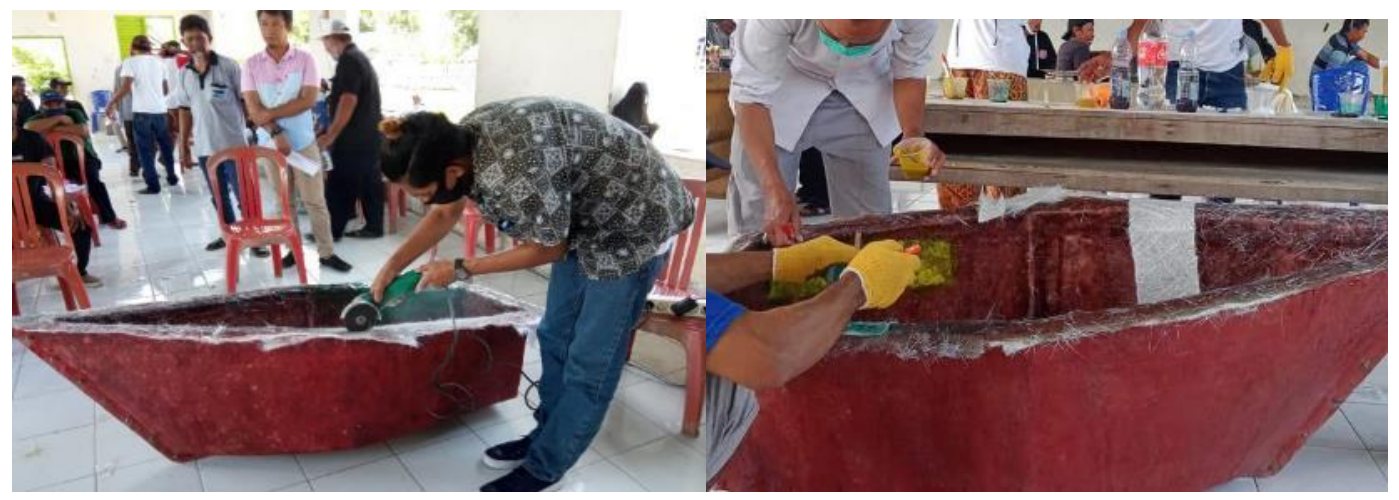

Gambar 7. Proses pembuatan perahu mini dan finishing

Setelah komposit pada cetakan mengering dilakukan finishing dengan cara memotong bagian yang lebih dari cetakan menggukanan gerinda. Dilanjutkan dengan membuka baut yang terdapat pada sisi cetakan sehingga cetakan dapat dilepas dengan cara menyungkil menggunakan linggis dan menghasilkan produk dari cetakan (Gambar 8).

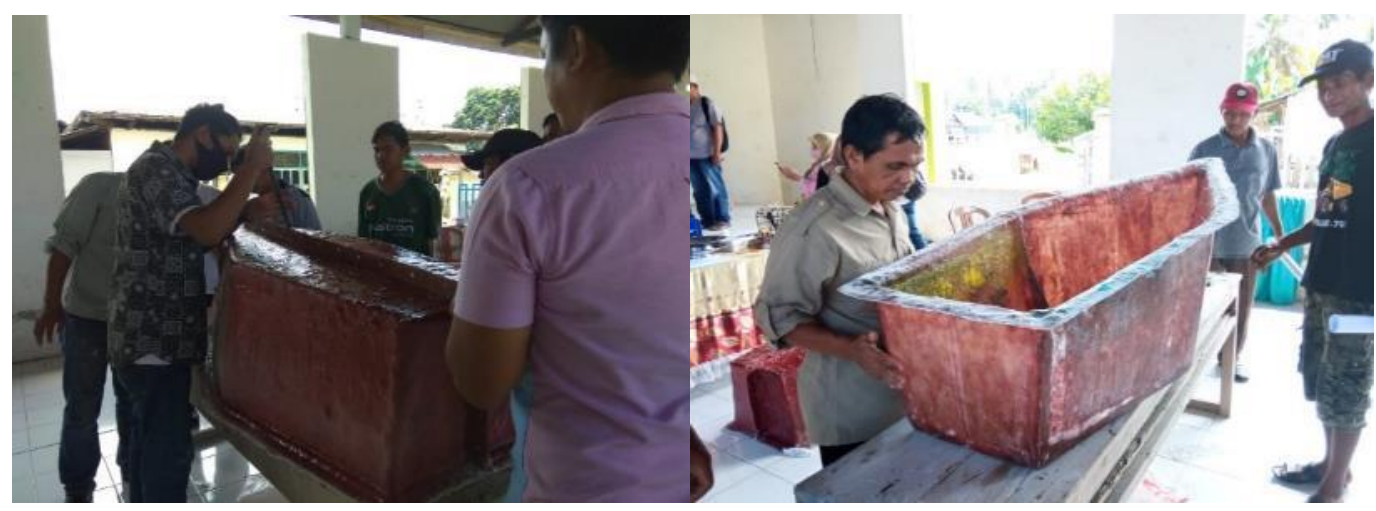

Gambar 8. Membuka cetakan/mall dan hasil pembuatan perahu mini

\section{Pengujian dan evaluasi akhir perahu fiberglass}

Tahapan ini dimaksudkan untuk memperoleh informasi (feed back) yang memungkinkan untuk dianalisis, mempelajari sikap-sikap, keyakinan, perilaku, dan karakteristik beberapa orang yang terlibat dalam pelatihan (Danial dan Warsiah, 2007). Kuesioner berupa angket atau daftar pertanyaan yang harus diisi atau dijawab oleh responden (peserta pelatihan) untuk mengukur tingkat 
pemahaman, kepedulian dan skill responden dalam menerima materi pelatihan. Diharapkan melalui kuesioner adalah untuk mengetahui keadaan atau jangka panjang pelatihan yang telah dilalui oleh responden dalam menyukseskan kegiatan pelatihan dan dapat dikembangkan ketahap selanjutnya. Berdasarkan tabel skala perbandingan pasangan seperti pada Tabel 1 Skala Perbandingan Pasangan (Saaty, 2008).

Tabel 1. Prioritas permasalahan pelatihan penggunaan material komposit dari responden

\begin{tabular}{cccl}
\hline No. & $\begin{array}{c}\text { Nilai Intensitas } \\
\text { Kepentingan }\end{array}$ & Defenisi & \multicolumn{1}{c}{ Penjelasan } \\
\hline 1 & 1 & $\begin{array}{c}\text { Sama } \\
\text { Pentingnya }\end{array}$ & $\begin{array}{l}\text { Kedua Variabel mempunyai pengaruh } \\
\text { yang sama pentingnya }\end{array}$ \\
\hline 2 & 3 & $\begin{array}{c}\text { SedikitLebih } \\
\text { Penting }\end{array}$ & $\begin{array}{l}\text { Sedikit lebih memihak pada satu variabel } \\
\text { dibandingkan dengan variabel lainnya. }\end{array}$ \\
\hline 3 & 5 & Lebih Penting & $\begin{array}{l}\text { Lebih memihak pada satu variabel } \\
\text { dibandingkan pasangannya. }\end{array}$ \\
\hline 5 & 7 & Sangat Penting & $\begin{array}{l}\text { Sangat memihak pada satu variabel } \\
\text { dibandingkan pasangannya. }\end{array}$ \\
\hline 6 & 9 & Mutlak Lebih & $\begin{array}{l}\text { Suatu variabel terbukti mutlak lebih } \\
\text { disukai di banding variabel lain pada } \\
\text { tingkat keyakinan tertinggi. }\end{array}$ \\
\hline
\end{tabular}

Sumber: Saaty, T.L. 2008

Kriteria kendala dalam pelatihan masyarakat nelayan di Desa Karang-karangan Kecamatan Bua Kabupaten Luwu Provinsi Sulawesi Selatan dengan menyebarkan kuesioner langsung ke nelayan yang menjadi peserta dalam Pelatihan Penerapan Teknologi Fiberglass pada perahu Tradisional Nelayan di Desa Karang-karangan sebanyak 5 kelompok nelayan dan setiap kelompok terdiri dari 5 orang. Dalam pelatihan ini peserta laki-laki sebanyak $72 \%$ dan wanita sebanyak $18 \%$. Rata-rata peserta berumur $30-$ 39 tahun mencapai $48 \%$. Penilaian terhadap permasalahan yang dihadapi oleh masyarakat nelayan terkait penggunaan material komposit dapat dilihat pada Tabel 2 berikut. 
Tabel 2. Prioritas permasalahan pelatihan penggunaan material komposit dari responden

\begin{tabular}{|c|c|c|c|c|c|c|c|c|c|c|c|}
\hline \multirow{2}{*}{ No. } & \multirow{2}{*}{ Jenis Masalah } & \multicolumn{9}{|c|}{$\begin{array}{l}\text { Jumlah Pilihan berdasarkan } \\
\text { Prioritas Permasalahan Nelayan }\end{array}$} & \multirow{2}{*}{ Tota } \\
\hline & & 1 & 2 & 3 & 4 & 5 & 6 & 7 & 8 & 9 & \\
\hline 1 & $\begin{array}{l}\text { Pemahaman terhadap } \\
\text { material komposit }\end{array}$ & 1 & 0 & 6 & 3 & 8 & 6 & 1 & 0 & 0 & 25 \\
\hline 2 & $\begin{array}{l}\text { Pemahaman penggunaan } \\
\text { material komposit }\end{array}$ & 0 & 3 & 1 & 9 & 3 & 4 & 3 & 2 & 0 & 25 \\
\hline 3 & $\begin{array}{l}\text { Minat peserta pelatihan } \\
\text { menggunakan material } \\
\text { komposit }\end{array}$ & 1 & 2 & 2 & 2 & 5 & 1 & 5 & 4 & 3 & 25 \\
\hline 4 & $\begin{array}{l}\text { Memahamani Peralatan } \\
\text { pelapisan komposit }\end{array}$ & 4 & 8 & 7 & 1 & 2 & 1 & 1 & 0 & 1 & 25 \\
\hline 5 & $\begin{array}{l}\text { Mengenal komposisi } \\
\text { campuran material } \\
\text { komposit }\end{array}$ & 0 & 1 & 0 & 2 & 3 & 5 & 4 & 6 & 4 & 25 \\
\hline 6 & $\begin{array}{l}\text { Waktu proses produksi } \\
\text { maket perahu tradisional }\end{array}$ & 0 & 1 & 0 & 2 & 2 & 2 & 6 & 7 & 5 & 25 \\
\hline 7 & $\begin{array}{l}\text { Resiko pembangunan } \\
\text { perahu tradisional }\end{array}$ & 0 & 3 & 3 & 2 & 3 & 4 & 1 & 6 & 3 & 25 \\
\hline 8 & $\begin{array}{l}\text { Pelatihan dapat dilanjutkan } \\
\text { untuk memproduksi }\end{array}$ & 0 & 0 & 1 & 2 & 2 & 10 & 8 & 0 & 2 & 25 \\
\hline
\end{tabular}

Sumber: Analisis data 2020

Tabel 2 di atas merupakan penjumlahan jumlah poin yang dinilai oleh responden terhadap permasalahan yang disajikan. Dengan demikian dapat diurutkan prioritas permasalahan dalam penggunaan kapal fiberglass dalam bentuk persen seperti pada Tabel 3 berikut. 
Tabel 3. Hasil urutan prioritas permasalahan dalam pelatihan penerapan teknologi fiberglass pada perahu tradisional nelayan

Selanjutnya dilakukan pembobotan nilai yang diperoleh masing-masing permasalahan dengan

\begin{tabular}{|c|c|c|c|c|c|}
\hline \multirow{2}{*}{$\begin{array}{c}\text { Hasil } \\
\text { No. Urut }\end{array}$} & \multirow{2}{*}{ Jenis Masalah } & \multicolumn{3}{|c|}{ Tanggapan Responden } & \multirow{2}{*}{$\begin{array}{c}\text { Bobot } \\
\text { Permaslahan } \\
\text { (Persen) }\end{array}$} \\
\hline & & $\begin{array}{l}\text { Jumlah } \\
\text { Pemilih }\end{array}$ & $\begin{array}{l}\text { Skor } \\
\text { (AHP) }\end{array}$ & $\Sigma$ & \\
\hline 1 & $\begin{array}{l}\text { Pelatihan dapat dilanjutkan untuk } \\
\text { memproduksi }\end{array}$ & 10 & 8 & 80 & 26 \\
\hline 2 & $\begin{array}{l}\text { Memahaman peralatan pelapisan } \\
\text { komposit }\end{array}$ & 8 & 7 & 56 & 18 \\
\hline 3 & $\begin{array}{l}\text { Minat peserta pelatihan } \\
\text { menggunakan material komposit }\end{array}$ & 8 & 6 & 48 & 16 \\
\hline 4 & $\begin{array}{l}\text { Pemahaman terhadap material } \\
\text { komposit }\end{array}$ & 7 & 5 & 35 & 11 \\
\hline 5 & $\begin{array}{l}\text { Pemahaman penggunaan } \\
\text { material komposit }\end{array}$ & 9 & 3 & 27 & 9 \\
\hline 6 & $\begin{array}{l}\text { Mengenal komposisi campuran } \\
\text { material komposit }\end{array}$ & 6 & 4 & 24 & 8 \\
\hline 7 & $\begin{array}{l}\text { Waktu proses produksi maket } \\
\text { perahu tradisional }\end{array}$ & 5 & 4 & 20 & 6 \\
\hline 8 & $\begin{array}{l}\text { Resiko pembangunan perahu } \\
\text { tradisional }\end{array}$ & 6 & 3 & 18 & 6 \\
\hline & & JUI & & 308 & \\
\hline
\end{tabular}

pembobotan AHP yang dirancang. Didapatkan grafik pembobotan prioritas permasalahan penggunaan fiberglass seperti pada Gambar 9 berikut. 


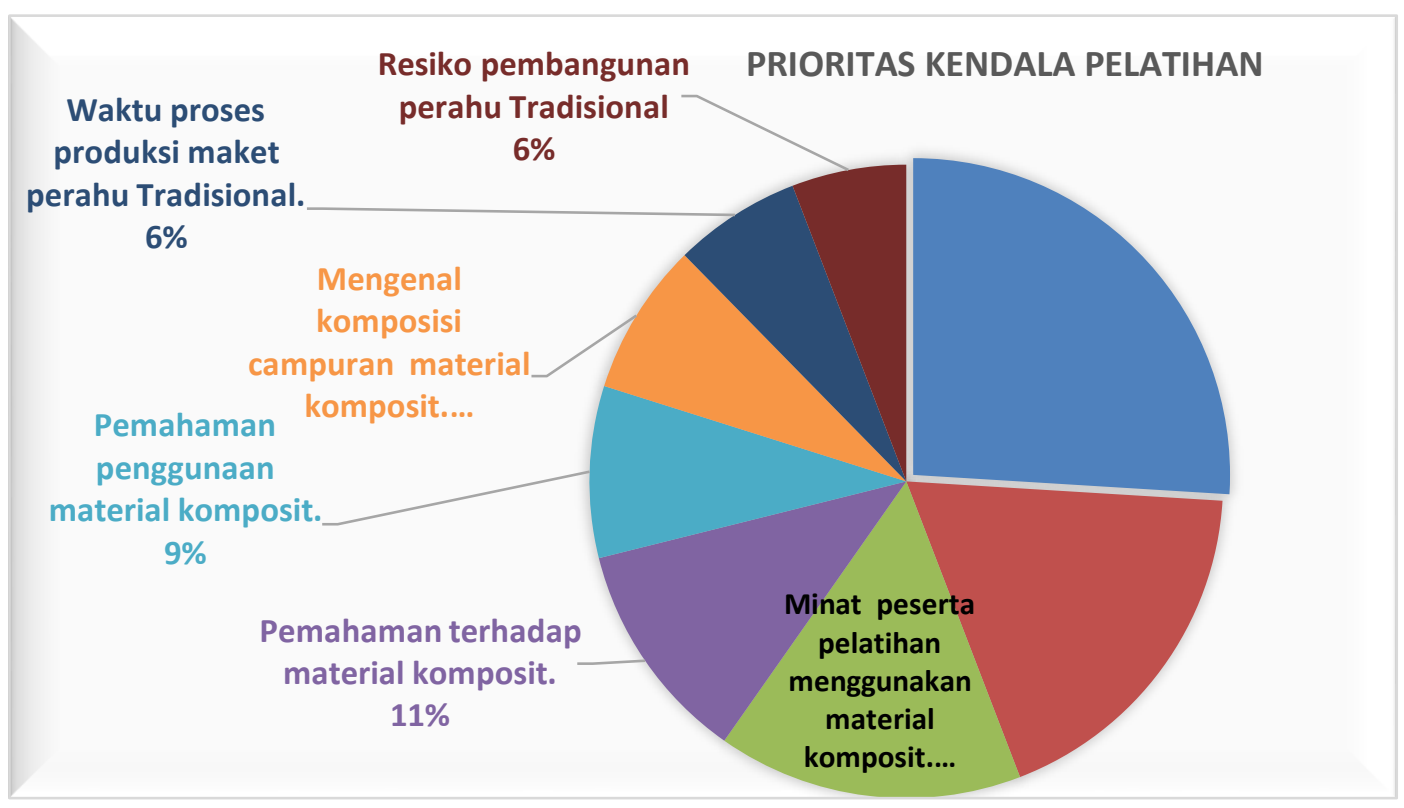

Gambar 9. Grafik bobot prioritas kriteria permasalahan dalam pelatihan

Gambar 9 di atas menjelaskan bahwa yang menjadi prioritas permasalahan bagi nelayan di Desa Karang-karangan Kecamatan Bua Kabupaten Luwu, adalah kelanjutan dari pelatihan untuk membuat atau memproduksi perahu nelayan tradisional bebahan dasar komposit dengan nilai bobot mencapai $26 \%$ dan yang menjadi permasalalhan kedua adalah tingginya minat peserta pelatihan dalam mengikuti pelatihan mencapai $16 \%$. Respon dan antusias serta rasa ingin tahu masyarakat terhadap peralatan yang digunakan dalam produksi atau pembuatan perahu tradisonal memberikan energi positif. Hal tersebut dikatakan oleh Bapak Fadli Kamaruddin(Ketua Kelompok Nelayan Malaja), alat yang digunakan harganya sangat terjangkau oleh masyarakat nelayan di Desa Karang-karangan dan dari hasil pengembangan pelatihan dapat diproduksi perahu trasdisional dengan biaya yang murah dibandingkan penggunaan material kayu serta perawatan yang tidak membutuhkan waktu yang lama dan biaya yang besar.

\section{KESIMPUAN DAN SARAN}

1. Hasil pelatihan pengenalan material komposit kepada masyarakat nelayan memberikan respon yang baik dalam mengikuti pelatihan.

2. Penggunaan material komposit sebagai pelapis pada perahu tradisional nelayan biaya perbaikannya lebih ringan dan mudah untuk dikerjakan.

3. Respon dan antusias serta rasa ingin tahu masyarakat terhadap peralatan yang digunakan dalam produksi atau pembuatan perahu tradisonal memberikan energi positif.

4. Minat peserta dalam pelatihan lanjutan mencapai $16 \%$ dan untuk memproduksi perahu berbahan dasar komposit mencapai $28 \%$.

\section{DAFTAR PUSTAKA}

Akovali, G.(2001).Handbook of Composite Fabrication, Rapra Technology Limited, United Kingdom. Anwar Khaerul (2012). Analisis Produksi Kapal Perikanan Berbahan Dasar Kayu danFiberglass. IPB Press: Bogor. 
Danial, E. AR dan Warsiah, N. (2007). Metode Penulisan Karya Ilmiah. Bandung: Laboratorium PKnFPIPS Universitas Pendidikan Indonesia.

Fardi(2017). Fabrikasi Kapal Fiberglass Sebagai Bahan Alternatif Pengganti KapalKayu Untuk Meningkatkan Produktifitas Nelayan Di Perairan Bengkalis. Jurnal Kapal.

Halid, I. dan Mallawa, A. (2017). Biodinamika Populasi untuk Penangkapan Ikan Baronang Lingkis Berkelanjutan. IPB Press: Bogor.

Marhayana S., Halid, I., Bakti, F.K. \& Halid, I. (2021). Pengelolaan dan Pemanfaatan Ekosistem Lamun untuk Perikanan Baronang Lingkis Berkelanjutan. Deepublish: Yogyakarta.

Mazumdar, S.K.(2002).Composites Manufacturing Material, Product, and Process Engineering, United States of America.

Nurul. (2018). Teknologi Terapan Perahu Fiberglass untuk Nelayan Sungai Kluet Kabupaten Aceh Selatan. Jurnal Cakrawala Maritim.

Saaty, T. L. (2008). Decision making with the analytic hierarchy process. Int. J. Services Sciences, 1 (1).

Sulaeman, B. (2012). Face Climbing Wall dari Material Fiberglass. Jurnal Pena Teknik, 1 (1).

Sulaeman, B. (2015). Pemanfaatan Limbah Krung Plastik. Jurnal Pena Teknik, 3 (1) 93-106. 